\title{
Removal of cyanobacterial blooms in Taihu Lake using local soils. I. Equilibrium and kinetic screening on the flocculation of Microcystis aeruginosa using commercially available clays and minerals
}

\author{
Gang Pan*, Ming-Ming Zhang, Hao Chen, Hua Zou, Hai Yan \\ State Key Laboratory of Environmental Aquatic Chemistry, Research Center for Eco-environmental Sciences, \\ Chinese Academy of Sciences, Beijing 100085, China
}

Received 8 March 2005; accepted 8 August 2005

Sepiolite was the most effective flocculant among 26 commercially available clays and minerals in removing harmful algal cells from freshwaters.

\begin{abstract}
Algal removal abilities of 26 clays/minerals were classified into three categories according to the 8-h equilibrium removal efficiency $\left(Q_{8 \mathrm{~h}}\right)$ and removal rate at a clay loading of $0.7 \mathrm{~g} / \mathrm{L}$. Type I clays (sepiolite, talc, ferric oxide, and kaolinite) had a $Q_{8 \mathrm{~h}}>90 \%$, a $t_{50}$ (time needed to remove $50 \%$ of the algae $)<15 \mathrm{~min}$, and a $t_{80}<2.5 \mathrm{~h}$. Type II clays ( 6 clays) had a $Q_{8 \mathrm{~h}} 50-90 \%$, a $t_{50}<2.5 \mathrm{~h}$, and a $t_{80}>2.5 \mathrm{~h}$. Type III clays (14 clays) with $Q_{8 \mathrm{~h}}<50 \%, t_{50}>8 \mathrm{~h}$ and $t_{80}>14 \mathrm{~h}$ had no practical value in removal of algal blooms. When the clay loading was reduced to $0.2 \mathrm{~g} / \mathrm{L}, Q_{8 \mathrm{~h}}$ for all the 25 materials decreased to below $60 \%$, except for sepiolite whose $Q_{8 \mathrm{~h}}$ remained about $97 \%$. The high efficiency for sepiolite to flocculate $M$. aeruginosa cells in freshwaters was due to the mechanism of netting and bridging effect.
\end{abstract}

(C) 2005 Elsevier Ltd. All rights reserved.

Keywords: Microcystis aeruginosa; Cyanobacterial bloom; Clay; Flocculation; Equilibrium; Kinetics

\section{Introduction}

Over the last two decades, harmful algal blooms (HABs) occurred more frequently in China, well in line with global trend (Anderson, 1997). Up to now, more than $60 \%$ of the lakes in China have been eutrophicated and suffered from HABs, where cyanobacterial Microcystis aeruginosa (M.A.) is one of the dominant species. The excessive growth of toxic M.A. greatly deteriorated the water quality (Yan et al., 2004a,b), damaged lakes' natural functions, and even threatened the drinking water resources. It has become one of the

\footnotetext{
* Corresponding author. Tel.: +86 1062849686 ; fax: +86 1062923563. E-mail address: gpan@mail.rcees.ac.cn (G. Pan).
}

top priorities in China to develop water-bloom control techniques that are safe, highly efficient and cost effective.

Several approaches, such as chemical, mechanical and biological techniques, have been studied (Anderson, 1997) in removal of HABs in seawater systems. Chemical methods that produce immediate results, e.g. chemical algaecide, have received less attention recently, mainly because of their adverse effects on other organisms and the expedited release of microcystins (Chorus and Bartram, 1999; EPA of China, 2000). Mechanical methods, e.g. harvesting algal cells by floating, fishing out, or centrifugation, can solve these problems without causing secondary contamination, but it is almost inapplicable to large natural waters because of the high cost. Biological and ecological restoration methods (Gu, 1992; Sengco et al., 2001) may work well in not too big areas, 
but the huge engineering backup and the relatively long time needed to implement this approach make it actually impractical for abrupt HABs over natural large areas. The newly developed virus control method is presently not a realistic option, mainly due to unsolved problems with its safety and handling (Drikas et al., 2001). Other biological methods, e.g. filter-feeding fish control and algal competition are not efficient or safe enough to treat large scale of HABs (Datta and Jana, 1998; Nagasaki et al., 1999). The application of commercially available flocculants (such as polyaluminum chloride and polyferric chloride) to natural waters is often rejected due to safety concerns and economic reasons (Becker, 1994).

It will be better if an HABs-control technique could change wastes into valuable products (Iranpour et al., 1999) with HABs and pollutants transformed in situ into contributors to the healthy ecosystem via biogeochemical processes (Pan, 1998). A very promising and environmentally friendly way to do this is to use natural, nontoxic and inexpensive clays to flocculate and remove algal cells (Anderson, 1997; Sengco and Anderson, 2004). Clays such as montmorillonite, kaolinite and phosphatic have been reported as the most effective flocculants with the lowest loading of $0.25 \mathrm{~g} / \mathrm{L}$ for a removal efficiency of 90\% (Avnimelech et al., 1982; Becker, 1994; Chorus and Bartram, 1999; Han and Kim, 2001; Pan, 1998; Sample, 2000; Sengco and Anderson, 2004; Yu et al., 1994a,b, 1995). However, the following problems still exist with regard to the clay technique: (1) unacceptable high clay loading $(>0.2 \mathrm{~g} / \mathrm{L})$ and thus the need to identify more effective clays; (2) clay flocculation efficiency decreased dramatically as salinity decreased and thus the need to develop novel clay modification techniques that make clay technique be applicable in freshwaters; (3) unclear mechanism and lack of systematic kinetic studies of clay-cell flocculation in fresh and sea waters; and (4) lack of further development of this technique that can turn harmful blooms into promoters to a healthier ecosystem in lakes (e.g. after the settlement of algal cells, it can further decompose algal toxins, permanently fixing phosphate and preventing second pollution from the sediment).

Here, in the first paper of the series of studies, we will systematically examine the kinetic and equilibrium properties of flocculation of 26 natural clays/minerals in removing Microcystis aeruginosa (M.A.). A general classification of natural clays is proposed based on the quantitative assessment of the kinetic and equilibrium flocculation data of the 26 clays/minerals in order to provide a general guidance in choosing natural clays/minerals. After finding the most effective clay and its mechanism in flocculating M.A. cells, the optimum method to modify clays in freshwaters can then be identified, and this will be systematically studied in the second paper of the series (Zou et al., 2006). Various factors that affect the performance of the clay technique (such as salinity, $\mathrm{pH}$, cell concentration, and growth phase etc.), field application of the technique and its long-term monitoring results in field enclosures in Taihu Lake will be presented in the third paper of the series (Pan et al., 2006).

\section{Materials and methods}

\subsection{Pre-treatment of clays}

All the clay samples listed in Table 1 were dried at $100{ }^{\circ} \mathrm{C}$ and sieved through 180 mesh $(<90 \mu \mathrm{m})$. Ferric oxide $\left(\mathrm{Fe}_{2} \mathrm{O}_{3}\right)$ and ferroferric oxide $\left(\mathrm{Fe}_{3} \mathrm{O}_{4}\right)$ were chemical reagents (A.R.). All other chemicals used in this study were of analytical grade.

To refine the impure sepiolite (sepiolite II, in Table 1), it was first sieved through a 70 mesh $(210 \mu \mathrm{m})$, dispersed thoroughly in distilled water and, after 30-min settlement, centrifuged and then dried, grounded and sieved through a 180 mesh. The purity of the refined sepiolite was found to be over $90 \%$ by X-ray diffraction (XRD).

\subsection{Culture}

M.A. was obtained from the FACHB, Institute of Hydrobiology, Chinese Academy of Sciences, and incubated in sterilized $250-\mathrm{mL}$ glass flasks containing $200 \mathrm{~mL}$ aqueous $M$. aeruginosa medium at $24 \pm 1{ }^{\circ} \mathrm{C}$ under fluorescent light (1000 lx, 12-h light/12-h dark). The M. aeruginosa medium was composed of $50 \mathrm{mg} / \mathrm{L} \mathrm{NaNO}_{3}, 50 \mathrm{mg} / \mathrm{L} \mathrm{Ca}\left(\mathrm{NO}_{3}\right)_{2} \cdot 4 \mathrm{H}_{2} \mathrm{O}, 100 \mathrm{mg} / \mathrm{L} \mathrm{KNO}_{3}, 500 \mathrm{mg} / \mathrm{L}$ Bicin, $100 \mathrm{mg} / \mathrm{L} \beta-\mathrm{C}_{3} \mathrm{H}_{7} \mathrm{O}_{6} \mathrm{PNa}_{2}, 40 \mathrm{mg} / \mathrm{L} \mathrm{Na} 2 \mathrm{SO}_{4}, 50 \mathrm{mg} / \mathrm{L} \mathrm{MgCl} \mathrm{Mg}_{2} \cdot 6 \mathrm{H}_{2} \mathrm{O}, 5 \mathrm{mg} / \mathrm{L}$ $\mathrm{Na}_{2}$ EDTA, $20 \mathrm{mg} / \mathrm{L} \mathrm{H} \mathrm{H}_{3}, 0.5 \mathrm{mg} / \mathrm{L} \mathrm{FeCl} \mathrm{F}_{3} \cdot 6 \mathrm{H}_{2} \mathrm{O}, 5 \mathrm{mg} / \mathrm{L} \mathrm{MnCl}_{2} \cdot 4 \mathrm{H}_{2} \mathrm{O}$, $0.5 \mathrm{mg} / \mathrm{L} \mathrm{ZnCl} 2,5 \mathrm{mg} / \mathrm{L} \mathrm{CoCl} 2 \cdot 6 \mathrm{H}_{2} \mathrm{O}$ and $0.8 \mathrm{mg} / \mathrm{L} \mathrm{Na} 2 \mathrm{MoO}_{4} \cdot 2 \mathrm{H}_{2} \mathrm{O}$. This medium was controlled to $\mathrm{pH} 8.5$ before autoclaving by adding either $0.1 \mathrm{~mol} / \mathrm{L}$ sodium carbonate solutions $\left(\mathrm{Na}_{2} \mathrm{CO}_{3}\right)$ or $0.1 \mathrm{~mol} / \mathrm{L} \mathrm{HCl}$ solutions.

\subsection{Flocculation experiment}

M.A. cells at late exponential growth stage were harvested by centrifugation (at $12000 \mathrm{rpm}$ ) and then suspended in $0.5 \% \mathrm{NaCl}$ solution in order to

Table 1

Characterization of the clays/minerals

\begin{tabular}{lllr}
\hline Name or code & $\begin{array}{l}\text { Specific gravity } \\
\left(\mathrm{g} / \mathrm{cm}^{3}\right)\end{array}$ & Particle size $(\mu \mathrm{m})$ & \\
\cline { 3 - 4 } & & Vol. wtd average & Mode \\
\hline Talc $(70 \%)^{\mathrm{a}}$ & $2.6-2.8$ & 19.4 & 16.3 \\
Ferric oxide & $4.9-5.3$ & 39.3 & 74.3 \\
Sepiolite I $(90 \%)$ & $2-2.5$ & 22.0 & 24.6 \\
Ferroferric oxide & 5.2 & 17.6 & 7.1 \\
Kaolinite $(80 \%)$ & $2.6-2.63$ & 7.4 & 9.4 \\
Argillanceous rocks & $2.23-2.28$ & 26.5 & 49.1 \\
Argil & $2.6-2.8$ & 20.9 & 40.2 \\
Sepiolite II & $2-2.5$ & 24.7 & 16.3 \\
Attapulgite $(70 \%)$ & $2.05-2.3$ & 26.6 & 32.4 \\
Silica mud & $2.6-2.65$ & 16.3 & 18.7 \\
Rectorite ${ }^{\mathrm{b}}(80 \%)$ & $2-3$ & 67.5 & 74.3 \\
Illite $(65 \%)$ & $2.6-2.9$ & 20.7 & 4.7 \\
Laterite & $2.75-3.0$ & 10.7 & 4.1 \\
Mica & $2.7-3.5$ & 65.0 & 74.3 \\
Clinoptilolite & 2.16 & 30.6 & 49.1 \\
Pumice I & $2.7-2.84$ & 14.3 & 10.1 \\
Ca-bentonite $(92 \%)$ & $2-2.7$ & 28.4 & 28.3 \\
White slimes & $2.6-2.8$ & 23.2 & 24.6 \\
Zeolite & $2-2.3$ & 45.7 & 56.4 \\
Pumice II & $2.3-2.4$ & 26.0 & 56.4 \\
Pumice III & $2.7-2.84$ & 36.4 & 56.4 \\
Volcanic scoria & $2.7-2.84$ & 42.3 & 56.4 \\
Tripoli & $0.4-0.9$ & 29.9 & 42.8 \\
Porcelain clay & $2.6-2.8$ & 43.4 & 42.8 \\
Potash feldspar & $2.5-2.6$ & 47.9 & 56.4 \\
Quartz (90\%) & 2.65 & 55.9 & 3.3 \\
Microcystis aeruginosa & & 3.4 & \\
\hline a The purites & & & \\
\hline
\end{tabular}

${ }^{a}$ The purities of clays are shown in brackets.

b Standard substance from the Institute of Geology, State Administration of Building Materials Industry. 
keep the cells alive. The initial cell concentration for all flocculation experiments here was set to $4.86 \times 10^{9}$ cells/L, or optical density of 0.100 at the wavelength of $680 \mathrm{~nm}\left(\mathrm{OD}_{680 \mathrm{~nm}}\right)$ (Clesceri et al., 1999). Concentration of chlorophyll- $a$, calibrated against direct microscope cell counts (Clesceri et al., 1999), was used to monitor the concentration change of M.A. cells during the flocculation experiment. Samples of M.A. cells filtrated onto $0.45 \mu \mathrm{m}$ cellulose acetate filters were completely dissolved using $10 \mathrm{~mL} 90 \%$ acetone solution and then measured for optical density at the wavelength of $665 \mathrm{~nm}$ $\left(A_{665 \mathrm{~nm}}\right)$. The chlorophyll- $a$ concentration was calculated by Chl- $a$ $(\mathrm{mg} / \mathrm{L})=13.4 \times A_{665} \mathrm{~nm}$.

A mass of $350 \mathrm{mg}$ clay was placed in an $800-\mathrm{mL}$ beaker before $500 \mathrm{~mL}$ of readily prepared M.A. suspension was added. The beakers were stirred (sixhead stirrer ZR3-6, made in Shenzhen, China) at $600 \mathrm{rpm}$ for $4 \mathrm{~min}$, followed by $50 \mathrm{rpm}$ for another $2 \mathrm{~min}$. The clock was started when the stirrer stopped. Concentrations of chlorophyll- $a$ of the suspensions was measured at 10, 30, 90, 240 and $480 \mathrm{~min}$. Flocculation kinetics was studied at clay loadings of $0.7,0.4,0.2$ and $0.1 \mathrm{~g} / \mathrm{L}$.

\subsection{Sample preparation for SEM examination}

Sediments obtained from the flocculation experiment were put onto $0.45 \mu \mathrm{m}$ cellulose acetate filters, pre-fixed with buffered $2.5 \%$ glutaraldehyde (pH 7.2) after being air-dried, and later post-fixed with buffered $1 \%$ Osmium tetraoxide at room temperature for $1 \mathrm{~h}$. The sample was then cleansed with the Milloning buffer, dehydrated through a series of 50-100\% ethanol solutions and dried at the critical-point of $41^{\circ} \mathrm{C}$. The filter was then mounted on the stub, coated with gold, and examined under a scanning electron microscope (JEOL JSM-35CF).

\section{Results}

\subsection{Equilibrium removal efficiency}

Fig. 1 shows grouped flocculation kinetic curves (i.e. groups I, II, III in Fig. 1 and Table 2) that are obtained from linkage distance of cluster analysis based on each kinetic curve of 26 clays using statistical software SPSS 10.0. Error bars represent the variation of removal efficiency in each group. All curves generally followed a power function, and reached equilibrium after $8 \mathrm{~h}$. We therefore define the removal

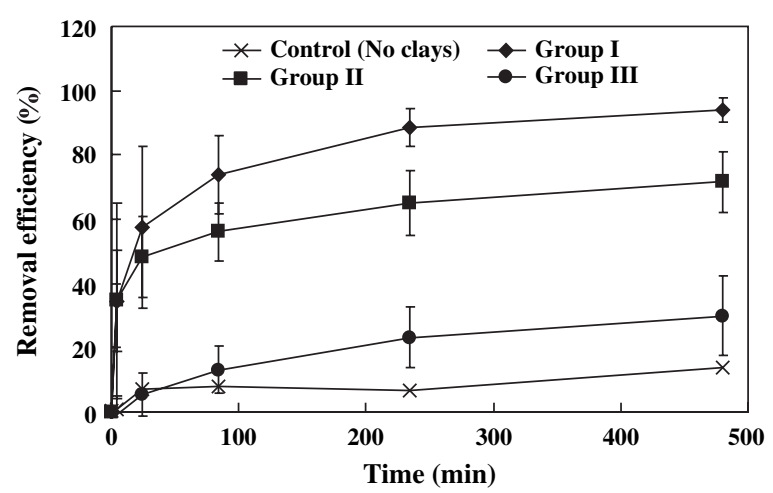

Fig. 1. Grouped flocculation kinetic curves (i.e. group I, II, III) that are based on each kinetic curve of 26 clays/minerals. Twenty-six clays/minerals were classified into three groups (I, II, III) based on their 8-h removal capacity $Q_{8 \mathrm{~h}}$. Error bars show the variation of equilibrium removal capacity in each group. The detailed grouping is summarized in Table 2. The initial Microcystis aeruginosa concentration was about $4.86 \times 10^{9}$ cells/L; the clay loading was $0.7 \mathrm{~g} / \mathrm{L}$. efficiency after $8 \mathrm{~h}$ as the $8 \mathrm{~h}$ equilibrium removal efficiency $\left(Q_{8 \mathrm{~h}}\right)$. Group I clays consisted of seven clays and iron oxides with $Q_{8 \mathrm{~h}}>85 \%$, group II clays displayed a lower $Q_{8 \mathrm{~h}}$ of $50-80 \%$, whereas group III clays had a $Q_{8 \mathrm{~h}}<50 \%$ which were of little value in clearing up harmful blooms in practice.

\subsection{Removal rate}

The flocculation kinetic curves were well described by the following equation:

$Q_{t}=Q_{0}\left[1-\exp \left(k t^{1 / 2}\right)\right]$

The removal rate $R_{t}\left(10^{6}\right.$ cells/ $\left.\left(\mathrm{mL} \mathrm{min}^{-1}\right)\right)$ can therefore be described as follow:

$R_{t}=\frac{\mathrm{d} Q_{t}}{\mathrm{~d} t}=-0.5 Q_{0} k t^{-1 / 2} \exp \left(k t^{1 / 2}\right)$

where $Q_{t}\left(10^{6}\right.$ cells $\left./ \mathrm{mL}\right)$ is the amount of $M$. aeruginosa removed at time $t, Q_{0}$ is the initial concentration of M. aeruginosa cells $\left(\times 10^{9}\right.$ cells/L), $k$ is the flocculation rate constant.

Fig. 2 shows the rate grouping results according to removal rates (i.e. rate-group $\mathrm{A}, \mathrm{B}$, and $\mathrm{C}$, also see Table 2) obtained from cluster analysis based on each kinetic data of 26 clays. Error bars represent the variation of removal rates in each group. Eq. (2) described how flocculation rates change with time (data in Fig. 2) with correlation coefficients for all the groups better than 0.89 . To make the kinetic parameters of practical usage, it is helpful to introduce the parameters $t_{50}$ (time needed to remove $50 \%$ of the M.A. cells) and $t_{80}$ (time needed to remove $80 \%$ of the M.A. cells) to describe and compare the kinetics of clay flocculation. Table 2 and Fig. 2 show that talc of Group A and eight clays in Group B (silica mud, sepiolite, kaolinite, argil, ferric oxide, ferroferric oxide, rectorite and illite) displayed much higher removal rates than the others. Moreover, the highest removal rates were found in the first minute (e.g. $3.52 \times 10^{6}, 1.23-2.17 \times 10^{6}$ and $<0.28 \times 10^{6}$ cells $/\left(\mathrm{mL} \mathrm{min}^{-1}\right)$ for Groups A, B and C, respectively) and all decreased greatly after $10 \mathrm{~min}$. The corresponding values of $t_{50}$ were 0.00026 (calculated), 11.4 and $1003.1 \mathrm{~min}$, and $t_{80} 6.0,329$ and $2978.8 \mathrm{~min}$ for Groups A, $\mathrm{B}$ and $\mathrm{C}$, respectively.

\subsection{Comparison and classification of clay flocculation in removal of M.A. cells}

Based on equilibrium data of $Q_{8 \mathrm{~h}}$ and kinetic data of $t_{50}$ and $t_{80}$, the flocculating abilities of the 26 clays/minerals could be classified into three categories (Types I, II and III). As shown in Table 2 and Figs. 1 and 2, five clays, namely talc, ferric oxide, sepiolite, ferroferric oxide and kaolinite, displayed $Q_{8 \mathrm{~h}}>90 \%, t_{50}<15 \mathrm{~min}$, and $t_{80}<2.5 \mathrm{~h}$, and were therefore classified as Type I clays, indicating the highest overall flocculating abilities. Type II clays included seven clays, namely argillaceous rock, argil, sepiolite II, attapulgite, silica mud, rectorite and illite, with $Q_{8 \mathrm{~h}} 50-90 \%, t_{50}<2.5 \mathrm{~h}$ and 
Table 2

Classification of Types I, II and III clays based on the equilibrium removal capacity $Q_{8 \mathrm{~h}}$ and removal rate data

\begin{tabular}{|c|c|c|c|c|c|c|}
\hline \multicolumn{3}{|c|}{ Grouping no. } & \multirow{2}{*}{$\begin{array}{l}\text { Name or } \\
\text { code }\end{array}$} & \multirow{2}{*}{$\begin{array}{l}t_{50} \\
\min \end{array}$} & \multirow{2}{*}{$\begin{array}{l}t_{80} \\
\min \end{array}$} & \multirow{2}{*}{$\begin{array}{l}Q_{8 \mathrm{~h}}, \\
\%\end{array}$} \\
\hline Type & Equ. & Rate & & & & \\
\hline \multirow[t]{5}{*}{ Type I } & I & A & Talc $(70 \%)$ & 0.00026 & 6.0 & 97.6 \\
\hline & I & B & Ferric oxide & 6.2 & 115.4 & 96.5 \\
\hline & I & B & Sepiolite I $(90 \%)$ & 3.1 & 83.4 & 96.3 \\
\hline & I & B & Ferroferric oxide & 13.9 & 146.3 & 95.0 \\
\hline & I & B & Kaolinite $(80 \%)$ & 4.7 & 120.2 & 93.9 \\
\hline \multirow[t]{7}{*}{ Type II } & I & $\mathrm{C}$ & Argillanceous rocks & 115.7 & 217.1 & 92.6 \\
\hline & I & $\mathrm{C}$ & Argil & 118.1 & 289.1 & 85.9 \\
\hline & II & $\mathrm{B}$ & Sepiolite II & 8.3 & 352.4 & 80.9 \\
\hline & II & $\mathrm{C}$ & Attapulgite $(70 \%)$ & 100.3 & 344.3 & 78.7 \\
\hline & II & B & Silica mud & 1.8 & 2171.3 & 73.8 \\
\hline & II & B & Rectorite $(80 \%)$ & 104.4 & 2331.9 & 65.8 \\
\hline & II & B & Illite $(65 \%)$ & 142.7 & 1781.5 & 58.6 \\
\hline \multirow[t]{14}{*}{ Type III } & III & $\mathrm{C}$ & Laterite & 456.9 & 863.3 & 46.2 \\
\hline & III & $\mathrm{C}$ & Mica & 871.0 & 4985.2 & 46.1 \\
\hline & III & $\mathrm{C}$ & Clinoptilolite & 624.5 & 1354.4 & 43.8 \\
\hline & III & $\mathrm{C}$ & Pumice I & 943.0 & 4122.7 & 35.6 \\
\hline & III & $\mathrm{C}$ & Ca-bentonite $(92 \%)$ & 865.1 & 2763.3 & 34.7 \\
\hline & III & $\mathrm{C}$ & White slimes & 1373.8 & 3803.0 & 34.1 \\
\hline & III & $\mathrm{C}$ & Zeolite & 605.9 & 987.0 & 30.5 \\
\hline & III & $\mathrm{C}$ & Pumice II & 1519.5 & 4657.5 & 29.1 \\
\hline & III & $\mathrm{C}$ & Pumice III & 2192.9 & 6302.0 & 29.1 \\
\hline & III & $\mathrm{C}$ & Volcanic scoria & 1123.8 & 2453.0 & 27.2 \\
\hline & III & $\mathrm{C}$ & Tripoli & 564.7 & 859.7 & 24.3 \\
\hline & III & $\mathrm{C}$ & Porcelain clay & 956.7 & 1448.3 & 24.1 \\
\hline & III & $\mathrm{C}$ & Potash feldspar & 99950.6 & 405010.0 & 9.0 \\
\hline & III & $\mathrm{C}$ & Quartz $(90 \%)$ & 12318.3 & 30149.0 & 4.0 \\
\hline
\end{tabular}

$t_{80}>2.5 \mathrm{~h}$. Argillaceous rocks and argil were put into this category mainly because they could not sink quickly enough due to their relatively low density, though they had displayed high $Q_{8 \mathrm{~h}}$. Silica mud had fairly high initial removal rates $\left(t_{50}\right.$ of 8.3 and $1.8 \mathrm{~min}$, respectively), but they could not keep the speed long enough, leading to an overall low $Q_{8 \mathrm{~h}}(<80 \%)$, and hence included into Type II clays. Type III clays included

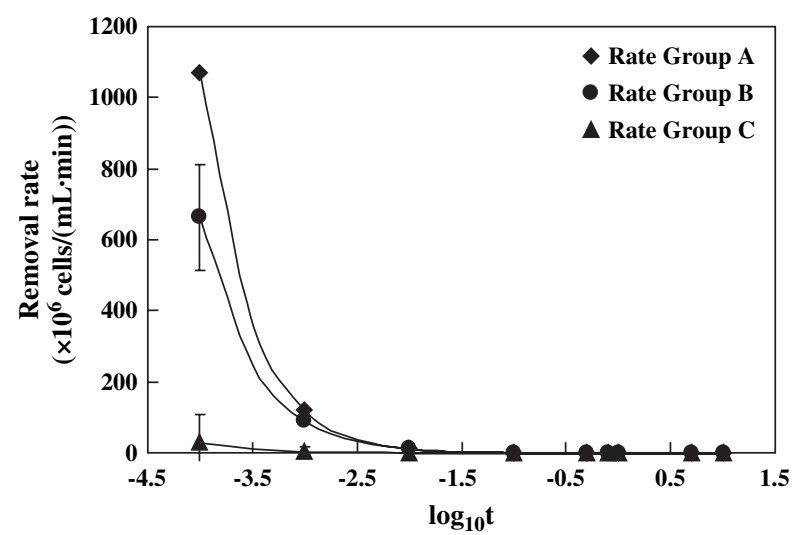

Fig. 2. Grouped removal rates (i.e. groups A, B, and C) based on each kinetic data of 26 clays. Twenty-six clays were grouped into three groups (A, B, C) according to the initial removal rates $(0-10 \mathrm{~min})$. Error bars show the variation of removal rate of the clays in each group. Detailed grouping is summarized in Table 2. The initial algal concentration was $4.86 \times 10^{9}$ cells $/ \mathrm{L}$, and the clay loading was $0.7 \mathrm{~g} / \mathrm{L}$. the rest of the clays/minerals, characterized by low $Q_{8 \mathrm{~h}}$ $(<50 \%)$ and low removal rates $\left(t_{50}>2.5 \mathrm{~h}\right.$ and $\left.t_{80}>14 \mathrm{~h}\right)$.

\subsection{Flocculating abilities at different clay loadings}

The flocculating abilities of clays varied a lot with clay loadings (Fig. 3). At a clay loading of $0.7 \mathrm{~g} / \mathrm{L}$, talc displayed the highest $Q_{8 \mathrm{~h}}(>96 \%)$. However, the $Q_{8 \mathrm{~h}}$ dropped very quickly to about $60 \%$ at a clay loading of $0.2 \mathrm{~g} / \mathrm{L}$. Kaolinite exhibited a similar trend, with its $Q_{8 \mathrm{~h}}$ dropping from $88 \%$ at a load of $0.7 \mathrm{~g} / \mathrm{L}$ to $43 \%$ at a load of $0.2 \mathrm{~g} / \mathrm{L}$. All the other clays followed the same pattern (shaded area in Fig. 3), except sepiolite, which maintained high flocculating ability within the entire range of clay loadings tested $(0.7-0.1 \mathrm{~g} / \mathrm{L})$. At a clay loading of $0.2 \mathrm{~g} / \mathrm{L}$, sepiolite displayed a high $Q_{8 \mathrm{~h}}(>97 \%)$, outdoing all the other materials tested. At a clay loading of $0.1 \mathrm{~g} / \mathrm{L}$, sepiolite could still remove about $90 \%$ of M.A. cells.

\section{Discussion}

It has been suggested (e.g. the DLVO flocculation theory) that the inter-particle forces (Van der Waals and electrostatic repulsion forces) play key roles in flocculation, along with the hydrodynamics and other conditions of the suspensions ( $\mathrm{pH}$, ion strength etc.). The size, shape, density, surface charge and chemical compositions of clay particles and cells could also contribute to the inter-particle forces, as well as to the movement and collision between clay particles and cells, and hence affect their flocculation efficiency (e.g. Han and Kim, 2001; Yu et al., 1994a,b, 1995). However, it is still not clear from the literature what mechanism is dominant in flocculating cells with clays in freshwaters, which is crucial for developing new clay modification methods. Therefore, there is need to discuss what mechanism makes sepiolite be much more effective in flocculating M.A. cells than other clays.

\subsection{Electrostatic neutralization}

Fig. 4 showed that both clay particles and M.A. cells are negatively charged in lake waters so that the reason why

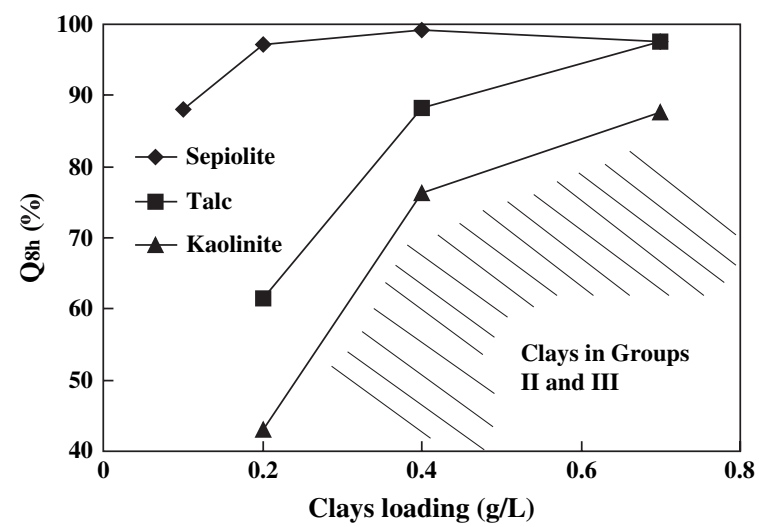

Fig. 3. Cells removal efficiency as a function of clay loading. 


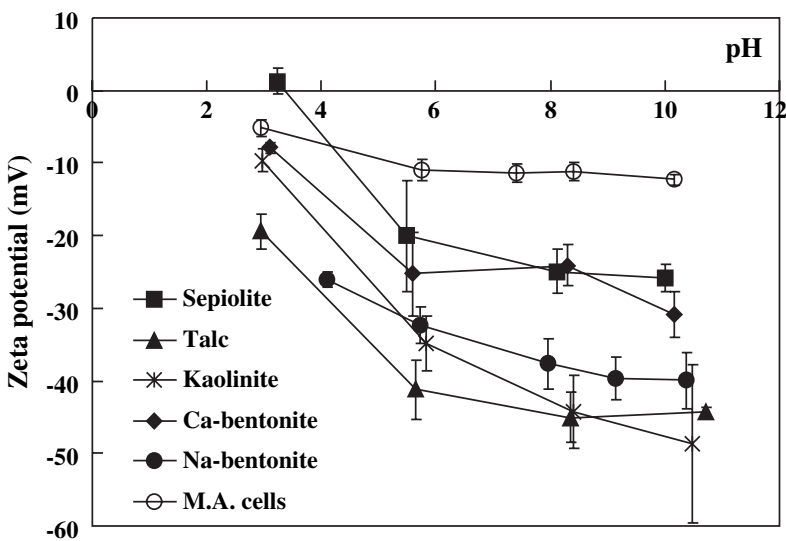

Fig. 4. Zeta potentials of clay particles and Microcystis aeruginosa cells as a function of $\mathrm{pH}$. The particles and cells were dispersed in $0.5 \% \mathrm{NaCl}$ solution.

clay particles flocculate M.A. cells cannot be explained through electrostatic neutralization. For example, the surface charge of sepiolite (Type I clay) and Ca-bentonite (Type III clay) were closest among all the clays tested here but they were in contrary ends of the spectrum of flocculation ability. Results in Fig. 4 indicated that the electrostatic forces were unlikely the dominant mechanism that regulated clay-cell flocculation in freshwaters. In the second paper of this series, it will be shown that modification of sepiolite particles to be positively charged only increase the rate of flocculation but not the equilibrium $Q_{8 \mathrm{~h}}$ significantly (Zou et al., 2006).

\subsection{Particle size}

The particle size distributions of the 26 clays and the M.A. cells are shown in Table 1. It has been proposed that algal removal efficiency of specific clay would reach its maximum when the clay particle size is close to that of the algal cells (Clesceri et al., 1999; Han and Kim, 2001; Yu et al., 1994a). The volume-weighted average particle size of the 26 clays fell in the range of $7-67 \mu \mathrm{m}$, much greater than that of M.A. cells $(3.4 \mu \mathrm{m})$. Therefore, a poor relationship between the particle size distribution and the $Q_{8 \mathrm{~h}}$ (data not shown here) was observed in this study. It is also important to note that sepiolite, which showed the highest $Q_{8 \mathrm{~h}}$ at a loading of $0.2 \mathrm{mg} / \mathrm{L}$ among the 26 clays, was not the finest-grained clays used, indicating that particle size was unlikely the dominant mechanism that regulated clay-cell flocculation in freshwaters.

\subsection{SEM study}

As the chemical composition of the clays also failed to correlate the removal efficiencies (Pan et al., 2003), the microstructure of the clay particles became another important factor to be considered. Fig. 5 includes two SEM images of the floccules obtained using kaolinite and sepiolite. Kaolinite particles of hard granular shape connected with the M.A. cells loosely. Sepiolite fibrous particles interwove like a frame or bridge, holding the cells tightly. This netting and bridging structure of sepiolite appeared to be a natural property of this mineral allowing it to catch the suspended cells more effectively. In the second paper of this series, it will be shown that modification of natural clays using netting and bridging reagents remarkably increased the flocculation efficiency of all solids (clays, soils, sediments) tested, confirming that netting and bridging function is indeed a dominant mechanism that regulated clay-cell flocculation in freshwaters (Zou et al., 2006).

It can also be seen from Fig. 5 that the M.A. cells kept their round shape in full after flocculation, indicating that clay flocculation did not destroy or break the cells. Unlike chemical reagents such as copper sulphate (Chorus and Bartram, 1999), clay flocculation did not result in an acute release of microcystins from the cells. When microcystins were sealed in the cells, it is possible for them to be biodegraded within days (Yan et al., 2004a,b).

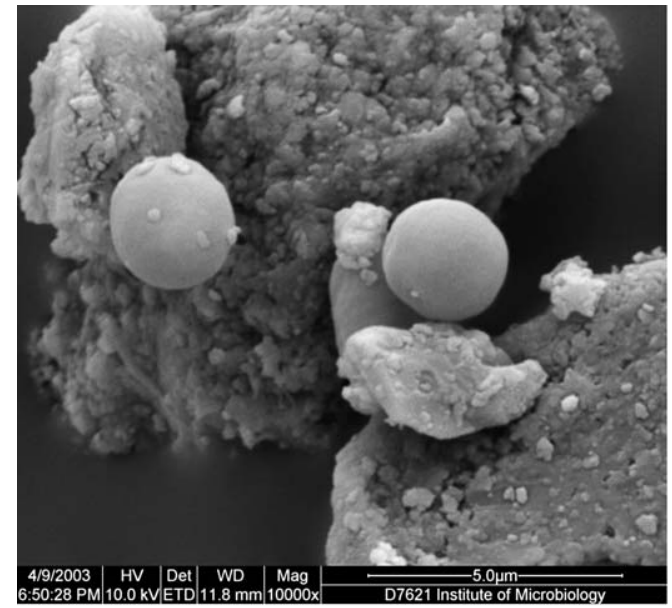

(a) Kaolinite + M.A. cells

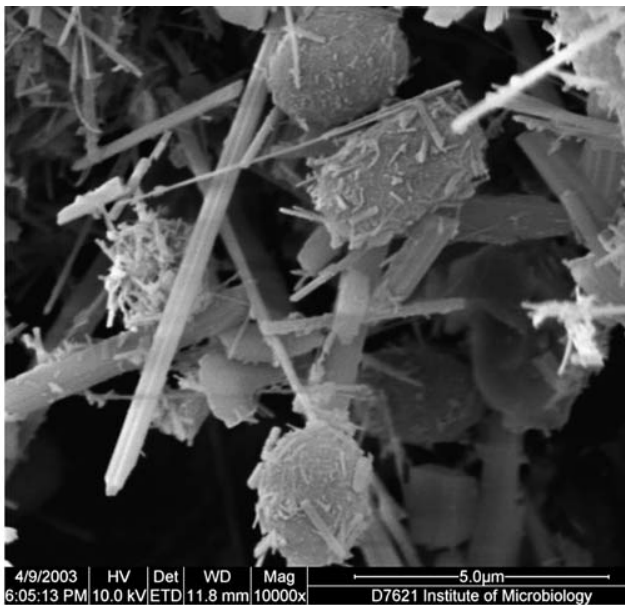

(b) Sepiolite + M.A. cells

Fig. 5. SEM images of the floccules of clay particles and Microcystis aeruginosa cells. (a) M. aeruginosa cells on the surface of granular kaolinite floccules; (b) M. aeruginosa cells trapped by sepiolite fibers. 


\section{Conclusions}

Kinetic and equilibrium properties of flocculation of M.A. cells were systematically studied based on 26 clays. Clays were classified into three categories (Types I, II and III) according to their removal rates and equilibrium removal efficiencies $Q_{8 \mathrm{~h}}$. A kinetic equation for clay-cell flocculation was proposed and the kinetic parameters of $t_{50}$, and $t_{80}$ were proposed and calculated for all the clays. Type I clays, i.e. sepiolite, talc, ferric oxide, ferroferric oxide and kaolinite, had much higher abilities to flocculate M.A. cells than other clays/minerals. Flocculating ability of clays decreased dramatically as clay loading decreased from $0.7 \mathrm{~g} / \mathrm{L}$ to $0.2 \mathrm{~g} / \mathrm{L}$, except sepiolite. At a clay loading of $0.2 \mathrm{~g} / \mathrm{L}$ in freshwaters, sepiolite had a $Q_{8 \mathrm{~h}}$ around $97 \%$ while all other clays had a $Q_{8 \mathrm{~h}}$ below $60 \%$. The outstanding flocculating ability of sepiolite was due to the unique fibrous structure of the mineral and the function of netting/bridging was found to be the dominant mechanism that regulated clay-cell flocculation in freshwaters.

\section{Acknowledgements}

The research was funded by the Key Technologies R\&D Programme: Study on Eco-techniques for Improving the Water Quality of Drinking Water Source in Meiliang Bay, Lake Taihu (2002AA601011), Chinese NNSF Grant No. 20177029 and National Key Project for Basic Research on the Processes of Lake Eutrophication and the Mechanism of Cyanobacterial Blooming (2002CB412308).

\section{References}

Anderson, D.M., 1997. Turning back the harmful red tide. Nature 388, 513-514. Avnimelech, Y., Troeger, B.W., Reed, L.W., 1982. Mutual flocculation of algae and clay: evidence and implications. Science 216, 63-65.

Becker, E.W., 1994. Microalgae-Biotechnology and Microbiology. Cambridge University Press, Cambridge.

Chorus, I., Bartram, J., 1999. Toxic Cyanobacteria in Water. F \& FN Spon Publisher, London.

Clesceri, L.S., Greenberg, A.E., Eaton, A.D., 1999. Standard Methods for the Examination of Water and Wastewater. American Public Health Association.

Datta, S., Jana, B.B., 1998. Control of bloom in a tropical lake: grazing efficiency of some herbivorous fishes. Fish Biology 53, 12-24.

Drikas, M., Chow, C.W.K., House, J., Burch, M.D., 2001. Using coagulation, flocculation, and settling to remove toxic cyanobacteria. Journal of American Water Works Association 93, 100-111.
Environmental Protection Agency of China, 2000. Chinese environmental annual reports of 2000. Journal of Environmental Protection 7, 1-6 (in Chinese).

Gu, J.X., 1992. The Characters and Applications of Nonmetal Mineral Materials (in Chinese). Wuhan University Publishing Company, pp. 125-136.

Han, M.Y., Kim, W., 2001. A theoretical consideration of algae removal with clays. Microchemical Journal 68, 157-161.

Iranpour, R., Stenstrom, M., Tchobanoglous, G., Miller, D., Wright, J., Vossoughi, M., 1999. Environmental engineering: energy value of replacing waste disposal with resource recovery. Science 285, 706-711.

Nagasaki, K., Tarutani, K., Yamaguchi, M., 1999. Growth characteristics of Heterosigma akashiwo virus and its possible use as a microbiological agent for red tide control. Applied and Environmental Microbiology 65, 898-902.

Pan, G., 1998. A method for simultaneously clearing up harmful algal blooms and harnessing organic pollutants to promote the primary productivity in the sea. UK patent publication number: GB2337749.

Pan, G., Zhang, M.M., Yan, H., Zou, H., Chen, H., 2003. Kinetics and mechanism of removing Microcystis aeruginosa using clay flocculation. Environmental Science 24, 1-10 (in Chinese).

Pan, G., Zou, H., Chen, H., Yuan, X.Z., Zhang, M.M., 2006. Removal of harmful cyanobacterial blooms in Taihu lake using local soils. III. Factors affecting the removal efficiency and an in situ field experiment using Chitosan-modified local soils. Environmental Pollution 141, 206-212.

Sample, I., 2000. Clay spray could spell death for algal blooms. New Scientist $165,16$.

Sengco, M.R., Li, A., Tugend, K., Kulis, D., Anderson, D.M., 2001. Removal of red- and brown-tide cells using clay flocculation. I. Laboratory culture experiments with Gymnodinium breve and Aureococcus anophagefferens. Marine Ecology Progress Series 210, 41-53.

Sengco, M.R., Anderson, D.M., 2004. Controlling harmful algal blooms through clay flocculation. Journal of Eukaryotic Microbiology 51, 169-172.

Yan, H., Pan, G., Zou, H., Song, L., Zhang, M.M., 2004a. Effects and nitrogen forms on the production of cyanobacterial toxin Microcystin-LR by an isolated Microcystis aeruginosa. Journal of Environmental Science and Health, Part A Environmental Science and Engineering and Toxic and Hazardous Substance Control 39, 2993-3003.

Yan, H., Pan, G., Zou, H., Li, X.L., Chen, H., 2004b. Effective removal of microcystins using carbon nanotubes embedded with bacteria. Chinese Science Bulletin 49, 1694-1698.

Yu, Z.M., Zou, J.Z., Ma, X.N., 1994a. Application of clay to removal of red tide organism. I. Coagulation of red tide organism with clays. Chinese Journal of Oceanology \& Limnology 12, 193-200.

Yu, Z.M., Zou, J.Z., Ma, X.N., 1994b. Application of clay to removal of red tide organism. II. Coagulation of different species of red tide organism with montmorillonite and effect of clay pretreatment. Chinese Journal of Oceanology \& Limnology 12, 316-324.

Yu, Z.M., Zou, J.Z., Ma, X.N., 1995. Application of clay to removal of red tide organism. III. The coagulation of kaolin on red tide organism. Chinese Journal of Oceanology \& Limnology 13, 62-70.

Zou, H., Pan, G., Chen, H., Yuan, X.Z., 2006. Removal of cyanobacterial blooms in Taihu lake using local soils. II. Effective removal of Microcystis aeruginosa using local soils and sediments modified by Chitosan. Environmental Pollution 141, 201-205. 